\title{
Translocation of Rarotonga Monarchs Pomarea dimidiata within the southern Cook Islands
}

\author{
HUGH A. ROBERTSON, IAN KARIKA and EDWARD K. SAUL
}

\begin{abstract}
Summary
The translocation of species to a new site plays an important role in the conservation of many threatened birds; however, the problems and processes involved in planning and implementing such translocations are rarely reported. In order to establish a second secure 'insurance' population of the endangered Rarotonga Monarch Pomarea dimidiata, or Kakerori, 30 young birds were moved from the Takitumu Conservation Area on Rarotonga to the 2,700 ha island of Atiu between 2001 and 2003. The translocation of this single-island endemic was to a site outside the historical range of the species, because the small, but rapidly growing, population on Rarotonga was considered to be highly vulnerable to a catastrophe, such as a cyclone, or the arrival of a new bird disease or predator. The translocation followed consultation with local communities, an assessment of the suitability of islands in the southern Cook Islands, and an assessment of the disease risk posed by the translocation. The translocation appears to have been successful because Rarotonga Monarchs have bred well in a variety of forest habitats on Atiu.
\end{abstract}

\section{Introduction}

In a review of bird conservation problems in the South Pacific, commissioned by the South Pacific Regional Environment Programme (SPREP) and the International Council for Bird Preservation (now BirdLife International) in the early 1980s, Hay (1986) identified the Rarotonga Monarch, or Kakerori, Pomarea dimidiata, as one of the species most urgently in need of conservation management.

The Rarotonga Monarch is a small (22 g) insectivorous forest passerine, which is endemic to Rarotonga $\left(21^{\circ} 15^{\prime} \mathrm{S}, 159^{\circ} 45^{\prime} \mathrm{W}\right)$ in the southern Cook Islands. Breeding pairs of Rarotonga Monarchs are strongly territorial and remain on their territory all year and for year after year. Youngsters (up to about 3 years old) often congregate in loose flocks on ridges and spurs away from the breeding territories that are usually in valleys sheltered from the prevailing south-east trade winds; however, each year a few yearlings establish territories and breed, and most birds have attempted to breed by their fourth year (Saul et al. 1998).

Historically, the genus Pomarea has been confined to forested 'high' volcanic islands in eastern Polynesia with an elevation over $372 \mathrm{~m}$ (Thibault and Meyer 2001); however, it may well have occupied other islands during its evolution in eastern Polynesia over the past 3-4 million years (Cibois et al. 2004). All nine species of Pomarea monarchs, as defined by Cibois et al. (2004), are either globally threatened or extinct (BirdLife International 2000, Cibois et al. 2004). Of the eight species in French Polynesia, four survive on 'high' islands (P. nigra on Tahiti, and P. iphis, 
P. mendozae and P. whitneyi in the Marquesas Islands; Thibault et al. 2002) while the other four species have been extirpated from other 'high' islands ( $P$. pomarea on Maupiti, and P. fluxa, P. mira and P. nukuhivae in the Marquesas Islands) (Figure 1 ). Cibois et al. (2004) used mitochondrial DNA markers to develop a phylogeny of Pomarea, and compared the dates of divergence with geological data on timing of volcanic activity in the region. The Rarotonga Monarch and Tahiti Monarch were basal in the Pomarea phylogenetic tree and they separated at least 3-4 million years ago. The age of islands in the Cook-Austral chain has been determined by K-Ar dating of volcanic rocks (Turner and Jarrard 1982), and this shows that the separation of Rarotonga Monarch as a distinct species happened several million years before the emergence of the relatively young island of Rarotonga about 2 million years ago. The ancestors of Rarotonga Monarch presumably inhabited one or more of the older volcanic islands (now 'low' raised-coral islands, or atolls) in the southern Cook Islands (Figure 2), such as Mangaia (19 million years old) to the south-east, or Aitutaki, Atiu, Mauke or Mitiaro (6-12 million years old) to the north or north-east, before colonizing Rarotonga in the past 2 million years.

There are no subfossil or historical records of Pomarea flycatchers away from Rarotonga, despite analysis of good collections of bird bones from limestone caves

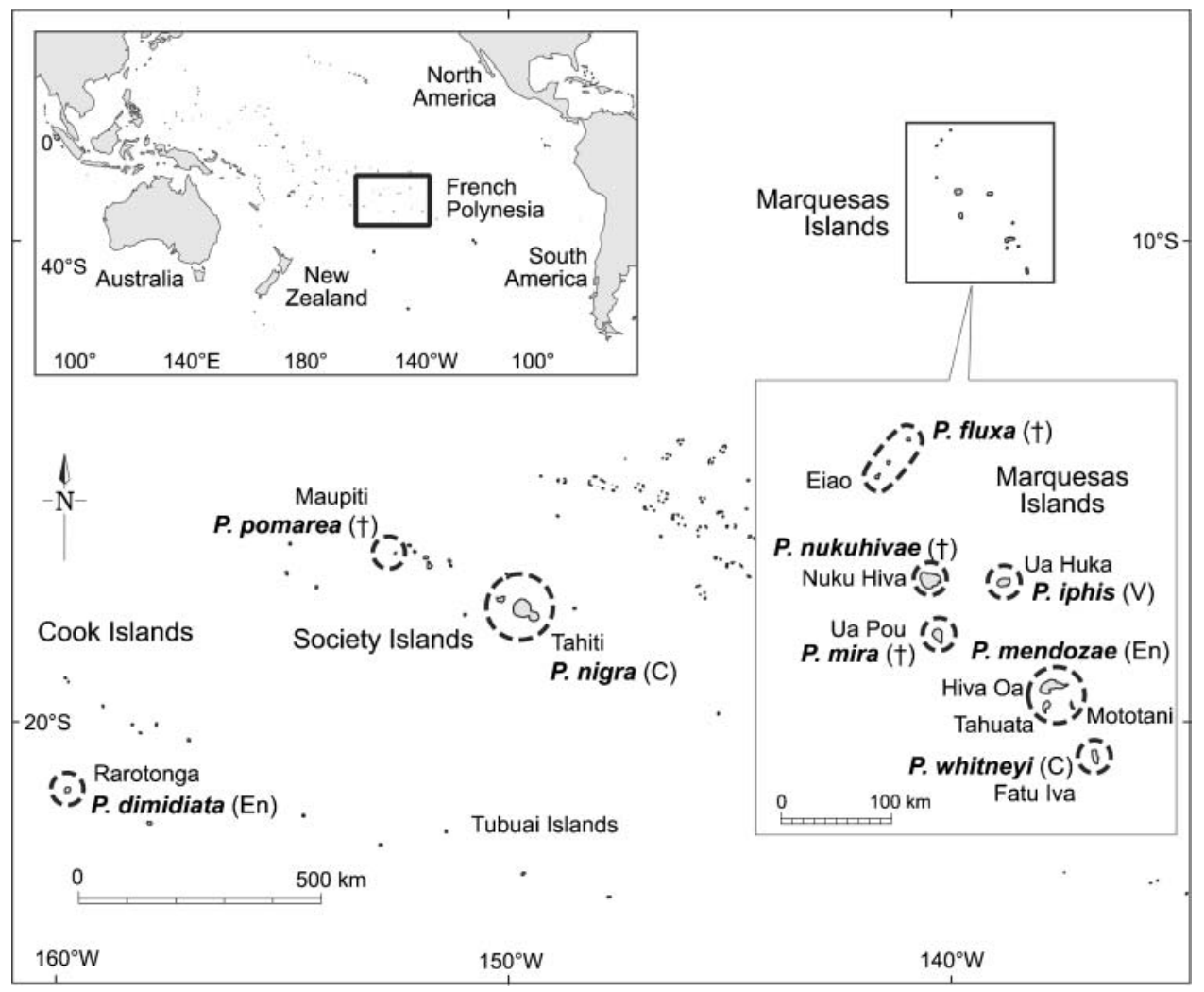

Figure 1. Map of eastern Polynesia showing the distribution of monarch flycatchers (Pomarea). The classification follows Cibois et al. (2004). 

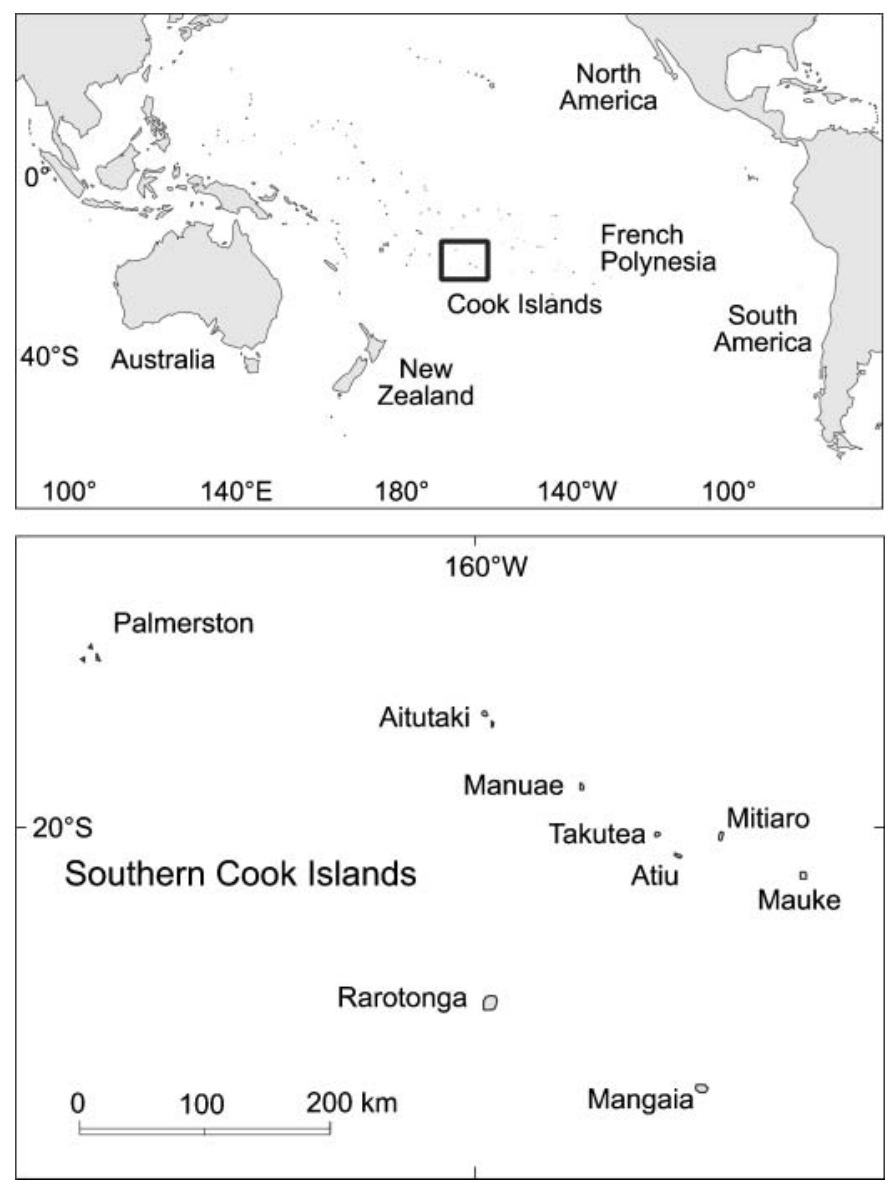

Figure 2. Map of the southern Cook Islands showing Rarotonga and the islands assessed as possible translocation sites.

and archaeological sites on Aitutaki, Atiu and Mangaia (Steadman 1985, 1991, Steadman and Kirch 1990). Saul et al. (1998) suggested that monarch flycatchers had probably lived on many smaller 'low' islands in eastern Polynesia but had died out through chance demographic events, or catastrophes such as severe cyclones, droughts or disease.

In the mid-180os, Rarotonga Monarchs were apparently common throughout Rarotonga, but they had virtually gone by the 188os (Gill 1885). They were thought to have become extinct shortly after five museum specimens were collected by W. E. Gudgeon and A. Seale in the early 19oos; however, in 1973 a small population was rediscovered in the rugged inland hills of the island (Holyoak and Thibault 1984). A thorough survey in 1987 found 38 birds, but over the next 2 years the population declined to 29 birds, mainly because of predation at nests by ship rats Rattus rattus (Robertson et al. 1994).

By 1989, the Rarotonga Monarch was among the 10 rarest bird species in the world, and was listed as Critically Endangered (Collar et al. 1994). During each breeding season since then, rats have been poisoned within the 155 ha of forested hill country 
of the Takitumu Conservation Area in south-eastern Rarotonga (Robertson et al. 1998). As a result, the Rarotonga Monarch population has rebounded (Figure 3), reaching 100 birds in 1995, 200 in 2000, and a minimum of 292 birds alive on Rarotonga in August 2003 (Robertson and Saul 2005). In 2000, the Rarotonga Monarch's threat ranking was downgraded from Critically Endangered to Endangered (BirdLife International 2000), one of a very few species to have been downgraded as a result of conservation management success rather than improved knowledge (Alison Stattersfield pers. comm.).

Despite this dramatic increase in population size, we considered that Rarotonga Monarchs remained at significant risk of extinction or substantial decline from a catastrophic event, because their entire species range covered only about 200 ha on the 6,700 ha island of Rarotonga.

A severe hurricane striking Rarotonga is perhaps the most obvious catastrophic danger. In the 14 years between 1969 and 1983, Thompson (1986) recorded that an average of 1.4 tropical cyclones (with mean wind speeds $>33$ knots $(61 \mathrm{~km} / \mathrm{h}$ ), and strong enough to damage human structures) affected the southern Cook Islands each summer or early autumn. Five of the 19 tropical cyclones in this period were classified as hurricanes, with a mean wind speed $>63$ knots $(117 \mathrm{~km} / \mathrm{h})$, and they were usually accompanied by great destruction. Gill (1885) considered that cyclones in three successive years 'desolated' some islands in the group, and caused the demise of Rarotonga Monarchs from lowland areas of Rarotonga. Many old mato trees Homalium acuminatum, the dominant canopy species in the Takitumu Conservation Area, show signs of having been seriously damaged by a severe hurricane in the past, with their large original trunk having been snapped off near the base, followed by the coppicing growth of several new, smaller trunks.

Because Rarotonga has the main international port, the only international airport and the main human population of the Cook Islands, it is especially vulnerable to the accidental or deliberate importation of new organisms (avian diseases, predators or

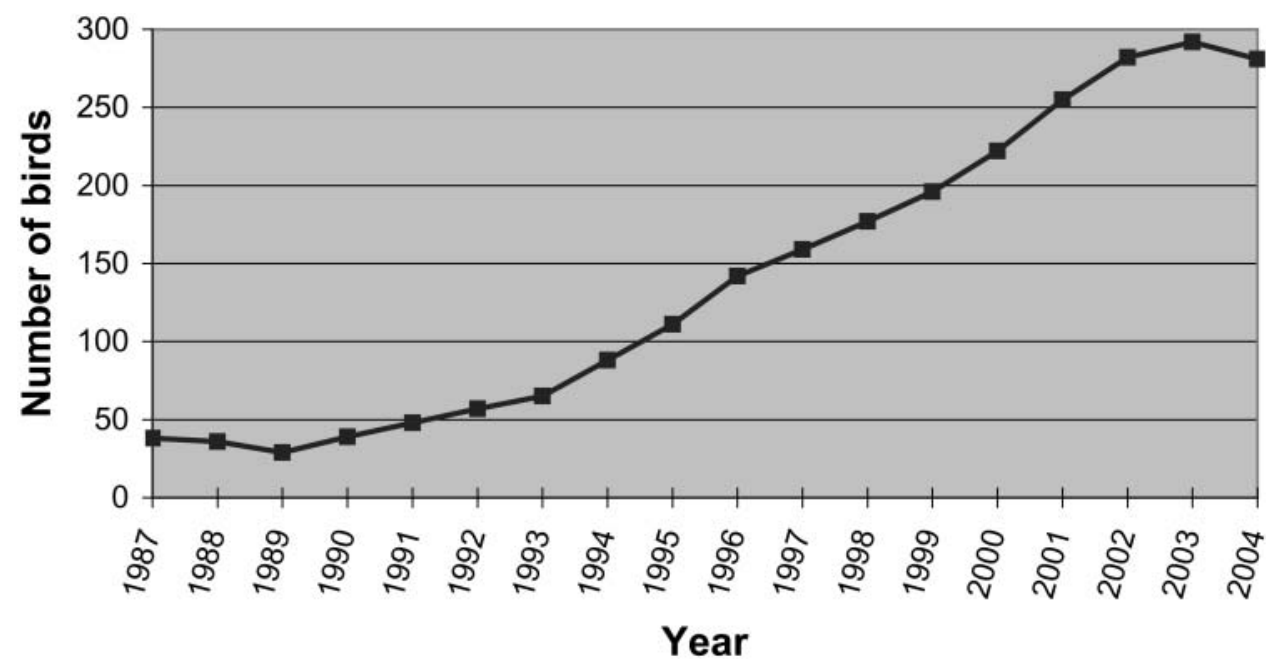

Figure 3. Annual census of Rarotonga Monarchs on Rarotonga, 1987-2004. 
competitors). Van Riper et al. (1986) described the devastating effects of introduced mosquito-borne Plasmodium haematozoa which caused avian malaria in many indigenous forest birds elsewhere in the Pacific, in Hawaii, and Steadman et al. (1990) showed that blood parasites are absent or extremely rare in Cook Islands birds, and so they are likely to have little natural resistance to avian malaria if it were to be accidentally introduced. Savidge (1987) described the near-extinction of the forest avifauna on Guam following the accidental introduction of brown tree snakes Boiga irregularis as a passive stowaway in cargo in the late 1940s or early 1950s, and Blanvillain et al. (2003) reported that Red-vented Bulbuls Pycnonotus cafer, originally introduced to Tahiti as an ornamental cage-bird in 1970, are now a threat to the survival of Tahiti Monarchs Pomarea nigra in French Polynesia.

In 1988, a recovery plan for Rarotonga Monarch outlined a programme to determine the species' conservation status, to identify causes for their decline, and, with management, to increase the population to an initial target of 50 birds; it also suggested the possible translocation of Rarotonga Monarchs to a predator-free island (Robertson et al. 1994). With this initial population target achieved, Saul (1995) updated the recovery plan, and promoted a feasibility study to establish an 'insurance' population of Rarotonga Monarch on another island in the southern Cooks which was free of ship rats. A South Pacific Regional Environment Programme/BirdLife International workshop on bird conservation priorities in Polynesia endorsed the translocation, but noted that no translocation protocols exist for South Pacific birds; and that poorly planned translocations could lead to damaging introductions, disease transmission, compromise of the source population, compromise of genetic identity and/or waste effort (Sherley 2001).

Translocations have been used frequently in the management of threatened birds, often to establish secure populations on islands (e.g. Komdeur et al. 1991, Butler and Merton 1992, Armstrong et al. 1995, Kuehler et al. 1997), but no attempt had previously been made to shift a threatened passerine species within the South Pacific region. Guidelines for translocations stress the need for a multidisciplinary approach by taking into account biological, socio-economic and legal requirements (Griffith et al. 1989, Towns et al. 1990, Black 1991, Armstrong and McLean 1995, IUCN 1998, Currie et al. 2003); however, relatively little has been published on the practical steps taken in planning and undertaking such a translocation (Armstrong and McLean 1995).

The present paper reports on the feasibility study, the translocations, and the results from monitoring of the new and source populations of Rarotonga Monarchs, partly to record the event, and partly to serve as a model for other translocations of threatened birds in the region.

\section{Island assessment}

\section{Community consultation}

The proposal to establish a second population of Rarotonga Monarchs was initially made under the auspices of the Cook Islands Environment Service (Saul 1995), but management of the Kakerori (Rarotonga Monarch) Recovery Programme was soon passed (1996) to the Takitumu Conservation Area Project, one of 17 community-led projects run in the South Pacific as part of the South Pacific Biodiversity Conservation 
Programme. Our initial consultation with landowners of the Takitumu Conservation Area, the home of Rarotonga Monarchs on Rarotonga, showed strong support for the concept of establishing a second, 'insurance' population of Rarotonga Monarchs, in case a catastrophe struck the local population. However, there was some concern expressed that having a second population may detract from the ecotourism business they were establishing, which was based on showing visitors the Rarotonga Monarch. Landowners readily accepted that the establishment of a second population elsewhere on Rarotonga would not afford adequate protection if a catastrophe struck the island, but they clearly stated that a within-country translocation was preferable to exporting the birds to another country. The imperative to establish a population on a second island was contrary to the IUCN (1998) guideline that translocations should be within the historical range of the species concerned, because Rarotonga Monarchs had never been recorded away from the island of Rarotonga.

Members of the landowning committee that managed the Takitumu Conservation Area attended meetings of the Island Councils of possible recipient islands. The committee members helped us to put the case for, gauge the interest in, and note any local concerns about translocating Rarotonga Monarchs to their island. Reactions among the five councils ranged from neutral to strongly supportive.

\section{Physical features}

Given that no other large 'high' islands exist in the Cook Islands, the translocation had to be to a smaller 'low' island. We assumed that the absence of monarch flycatchers from smaller islands and atolls in the region was an artefact of demographic events and/or catastrophes (cyclones or droughts) affecting the small populations over the last million years or more, rather than the unsuitability of these islands per se. 'High' islands are generally large and varied islands with diverse vegetation, and so have a greater range of habitats and carrying capacity for birds. They are also wetter and less drought-prone; for example, the outer islands in the southern Cooks all have annual rainfall of less than 2,000 $\mathrm{mm}$ and in the driest years have much less than half the normal rainfall, whereas the Takitumu Conservation Area receives over 3,000 $\mathrm{mm}$ and the peaks of Rarotonga receive over $4,500 \mathrm{~mm}$ rainfall each year; the driest years still have over half the annual rainfall (Thompson 1986).

We decided that the translocation should preferably be done within the southern group of Cook Islands (Figure 2) because there were regular air services between Rarotonga and five other islands (Aitutaki, Atiu, Mitiaro, Mauke and Mangaia), all of which lie $230-320 \mathrm{~km}$ from Rarotonga. A translocation to Palmerston Atoll or islands in the northern group, which is at least $900 \mathrm{~km}$ from Rarotonga, would have involved a combination of air charter and boat travel.

Given that the usual territory size of Rarotonga Monarchs in the Takitumu Conservation Area is about 2 ha (Saul et al. 1998), and room was also needed for nonterritorial birds, we considered that an island smaller than 500 ha was probably not suitable for the long-term viability of an 'insurance' population, and so the 120 ha uninhabited sand cay of Takutea, and Palmerston atoll (26o ha), were ruled out. The two islands (Motu Te Au o Tu and Motu Manuae) in the atoll of Manuae had a combined area of 617 ha, but they were separated by about $1.5 \mathrm{~km}$ of lagoon. We considered that the coconut Cocos plantation which covers most of the islands (Franklin and Steadman 1991) is, at best, marginal habitat for Rarotonga Monarch, 
and this, combined with the difficulty of getting birds there (by air and then by a $100 \mathrm{~km}$ sea voyage) made Manuae a low-priority site to investigate. The five large $(1,800-6,700 \mathrm{ha})$ and accessible islands in the southern Cook Islands therefore considered were: Aitutaki, Atiu, Mangaia, Mauke and Mitiaro. Aitutaki is an 'almostatoll' with one main volcanic island ( $124 \mathrm{~m}$ ) set in a typical atoll while the other four islands are composed of highly weathered low volcanic hills (15-169 m) surrounded by a ring of raised coral limestone (makatea) and a narrow fringing reef (Franklin and Steadman 1991).

\section{Presence of predators}

The key priority in our island assessment was that ship rats should be absent from the island. Research on Rarotonga, and elsewhere in eastern Polynesia, had established that ship (black) rats were primarily responsible for the demise of monarch flycatchers in the region (Robertson et al. 1994, Seitre and Seitre 1992, Thibault and Meyer 2001, Thibault et al. 2002).

We were not so concerned by the presence of Pacific rats (kiore) Rattus exulans, Norway rats $R$. norvegicus, cats Felis catus, Long-tailed Cuckoos Eudynamys tahitica or Indian Mynas Acridotheres tristis because all but Indian Mynas were on Rarotonga in the early 1800 s when Rarotonga Monarchs were common. Although Indian Mynas are regarded as a threat to Tahiti Monarchs (Blanvillain et al. 2003), they were present in the Takitumu Conservation Area but not obviously involved in any of the over 6o nest failures recorded on Rarotonga between 1987 and 1997 (Saul et al. 1998). Kingfishers Todiramphus spp., which are absent from Rarotonga but present on some of the outer islands in the Southern Cooks, are potential nest predators because a closely related species in New Zealand, Halcyon sancta, occasionally kills small birds (Heather and Robertson 2000).

We searched the literature and the Cook Islands Natural Heritage Project database (G. McCormack unpubl.) for distribution records of ship rats in the southern Cook Islands. During inspections of the five candidate islands, E. S. set rat traps baited with roasted coconut meat to determine which rat species were present. Although it is impossible to confirm that ship rats are absent from an island, we were able to assign a low ranking to three islands (Mangaia, Mauke and Mitiaro) where ship rats were definitely present.

\section{Habitat}

Rarotonga Monarchs are forest-dwelling birds that feed almost exclusively on invertebrates. Nowadays, they prefer sheltered tall forest in wet hill country for breeding, but they sometimes nest in shorter vegetation on spurs and ridges (Saul et al. 1998), habitats more frequently used throughout the year by non-territorial immature birds (Sanders et al. 1996, Saul et al. 1998). In the early 180os, they apparently also inhabited the drier lowland areas of Rarotonga, but retreated inland with the presumed arrival of ship rats in the late 180os (Robertson et al. 1994), or because of repeated cyclones (Gill 1885). Other monarch flycatchers in French Polynesia show a similar preference for dense vegetation in wet valleys or montane forests; however, some pairs live in drier forests on islands free of ship rats, and immature birds often visit dry forest and scrub (Thibault and Meyer 2001). 
Sanders et al. (1996) found only a weak association between habitat composition and breeding success, and this indicated that Rarotonga Monarchs are not highly dependent on specific habitat components. Saul et al. (1998) found that most nests were built in the outer branches of sub-canopy trees overhanging a stream or dry stream-bed. Over $55 \%$ of the 309 nests they found were in mato or turina (Hernandia moerenhoutiana) trees, but a total of 21 species of trees or shrubs were used. Mato was used approximately in proportion to its abundance in the Takitumu Conservation Area, but turina was used preferentially, probably because its large leaves provide good shelter from sun and rain; small- or sparsely-leaved trees were generally avoided. Nests were made of interwoven strands of moss (especially live Aerobryopsis), lichen and liverwort, with spider egg-cases woven into the outer layers, and were lined with short pieces of plant fibre such as from 'au (Hibiscus tiliaceus) bark.

The vegetation of the main island of Aitutaki has been described by Fosberg (1975) and Stoddart (1975), and quantitative analyses of the native vegetation are available for the other four islands (Franklin and Steadman 1991, Merlin 1991, Franklin and Merlin 1992). A visual assessment of the current extent and quality of vegetation on all islands was made during visits by E. S. and members of the Takitumu Conservation Area committee in 1999 and 2000. All five islands had a sufficient area $\left(>_{500}\right.$ ha) of potentially suitable habitat available, and all had vegetated stream valleys. Atiu stood out as having a large area of potentially suitable habitat (c. 1,740 ha), goodquality vegetation, and good availability of suitable large-leaved trees for nesting in. From Franklin and Steadman's (1991) mapping of the land cover of Atiu, we considered that about 880 ha of dense $10-15 \mathrm{~m}$ tall makatea forest, a vegetation type which does not exist on Rarotonga, was suitable habitat. It contained many tree species used by Rarotonga Monarchs, and turina was one of the dominant species, along with karaka Elaeocarpus tongatus (Franklin and Merlin 1992). About 440 ha was littoral or coastal forest, dominated by Casuarina, Pisonia, Guettarda, Barringtoni, Hernandia nymphaeifolia or coconut, species absent or rare in the existing range of Rarotonga Monarchs but which may provide suitable feeding and nesting opportunities. The other 320 ha of suitable forest habitat was inland, and the tall riverine forest ( $155 \mathrm{ha}$ ) and secondary forests ( $80 \mathrm{ha}$ ) were particularly similar to some habitats occupied on Rarotonga. The one concern, however, was the absence of Aerobryopsis moss on Atiu, because it is the main component of Rarotonga Monarch nests on Rarotonga.

\section{Presence of competitors}

Like other remote oceanic islands, the species diversity of landbirds in the Cook Islands is low. The whole country now supports 11 species of native landbirds, three introduced species, and a migrant cuckoo (Holyoak 1980); however, the landbird assemblage was greater in prehistoric times (Steadman 1991, Steadman and Kirch 1990). Of the 15 extant species, only seven primarily eat small insects: Jungle Fowl Gallus gallus, Spotless Crake Porzana tabuensis, Atiu Swiftlet Collocalia sawtelli, Cook Islands Warbler Acrocephalus kerearako, Rarotonga Monarch, Rarotonga Starling Aplonis cinerascens and Indian Myna. The Mangaia Kingfisher Todiramphus ruficollaris, Chattering Kingfisher T. tuta and Long-tailed Cuckoo all eat large insects 
and lizards, but are unlikely to compete with Rarotonga Monarchs for small invertebrates. We judged that only the warbler and swiftlet were possible competitors with Rarotonga Monarchs on the outer islands in the southern Cooks.

The Cook Islands Warbler is a Near-Threatened species which is common on both Mangaia and Mitiaro (BirdLife International 2000). After our first translocation of Rarotonga Monarchs to Atiu, we discovered that some local boy scouts had trapped a few birds on Mitiaro and brought them to Atiu a couple of years earlier, but the lack of subsequent sightings suggests that they failed to become established. We have observed that the habitats warblers occupy are similar to those occupied by Rarotonga Monarchs, and they glean invertebrates from leaves and branches in a similar way to Rarotonga Monarchs; therefore, there is a possibility of competition between the two species.

The Atiu Swiftlet is a Vulnerable species now restricted to Atiu (BirdLife International 2000). E. S. observed that the swiftlets fed solely on the aerial 'plankton' of minute to small soft-bodied insects and spiders while in constant flight, especially over open fernland and taro plantations, but occasionally over forest, and so were not likely to compete with Rarotonga Monarchs, which mainly glean from the surface of leaves and branches within the forest.

\section{Impact of Rarotonga Monarchs on island invertebrates}

The invertebrate fauna of the five possible recipient islands is poorly known, but is likely to be mostly mobile 'island-hopping' species that are widespread in the region, or species accidentally introduced with plants and fruit being brought to the islands. The extant invertebrate fauna has survived the significant changes to habitats, predators and competitors since human colonization in the past couple of millennia.

\section{Island selection}

Our overall conclusion was that Atiu Island, alternatively named Enua Manu 'the Island of Birds', was the most suitable island in the southern Cook Islands for the translocation of Raratonga Monarchs, because it was not known to have ship rats, over $60 \%$ of the 2,693 ha island was suitable forest habitat, it had a good range of trees used by Rarotonga Monarch including an abundance of their favourite nesting tree, there were no known competitors, it was accessible with a regular air service and, importantly, we had very strong support from the Island Council, which has a longstanding conservation ethic.

We recognized that kiore, cats and Chattering Kingfishers could be predators, but hypothesized that a population of Rarotonga Monarchs could cope with their presence. Our main concern was that the absence of Aerobryopsis moss on the island meant Rarotonga Monarchs would not have access to the main plant used in nest construction on Rarotonga; however, we felt that these concerns did not detract sufficiently to prevent us from proceeding with the translocations.

\section{Disease screening}

Given the absence of blood parasites detected in 79 blood smears taken from nine species of indigenous birds (but not Rarotonga Monarchs) and Indian Mynas in the 
southern Cook Islands (Steadman et al. 1990), and the consistently low annual mortality of Rarotonga Monarchs since predator control began in 1989 (Robertson et al. 1994), the chances of Rarotonga Monarchs carrying a serious haematozoan, particularly the devastating Plasmodium, seemed remote. However, all translocations have the potential to transmit diseases (Griffith et al. 1993, Viggers et al. 1993.), and because the earlier blood samples had included only two birds from Rarotonga, we decided to screen Rarotonga Monarchs and two other species they may have occasional contact with in the Takitumu Conservation Area. This screening had to be done beforehand, because there were no skills or experience available on Rarotonga to hold an insectivorous species in quarantine for an extended period while samples were processed in the nearest diagnostic laboratory in New Zealand.

Steadman et al. (1990) analysed blood smears from 20 birds of seven species on Atiu, and there had been no known recent bird disease problems on Atiu (R. Malcolm pers. comm.). With limited resources available to us for disease screening, we accepted the low risk that there were endemic haematozoa or other novel diseases in wild bird populations on Atiu that could kill released Rarotonga Monarchs.

Preparations for a possible translocation started in 1999, when smears were made from blood samples taken from the brachial veins of 16 free-living Rarotonga Monarchs, one Rarotonga Starling and five Indian Mynas on Rarotonga. Samples were analysed by Alpha Scientific Ltd in Hamilton, New Zealand.

None of the 22 birds showed any clinical abnormalities in the field. Differential white blood cell counts (WBC) (Table 1 ) showed that three of the 16 samples from Rarotonga Monarchs were slightly anomalous compared with the other samples. Two birds had elevated lymphocytes, most likely due to the stress of capture, and one bird had low counts of lymphocytes and high basophils consistent with an early infection or inflammatory disease (R. Jakob-Hoff pers. comm.). All three birds bred within 2 months of the blood sampling, and were alive 12 months later. One of the five Indian Mynas had a low WBC but high basophils consistent with a recent injury or parasitism (R. Jakob-Hoff pers. comm.). All five Indian Mynas tested had consistently high heterophils and low lymphocytes compared with a reference range from captive birds (Petrak 1982), and probably reflected a difference between free-living and captive conditions rather than a disease concern in the Rarotongan population (R. Jakob-Hoff pers. comm.).

Red cells and thrombocyte morphology and numbers appeared normal in all 22 samples. No blood parasites were detected in any of these samples, nor in six additional samples (from two Rarotonga Monarchs and four Indian Mynas) that were not suitable for reading WBCs (R. Lanham pers. comm.).

\section{Disease risk}

No blood parasites have been detected in 107 samples from II species of southern Cook Islands birds, and so it seemed that the introduction of Rarotonga Monarchs to Atiu was likely to pose a very low risk of introducing a novel blood parasite to the island. There was probably a greater risk to the islands' birdlife, and poultry in particular, from the occasional transportation of domestic poultry between islands, or from migrant birds such as Long-tailed Cuckoos, waders and seabirds, making their regular visits to the island. No known bird disease was present on Atiu to affect Rarotonga Monarchs on their arrival. 


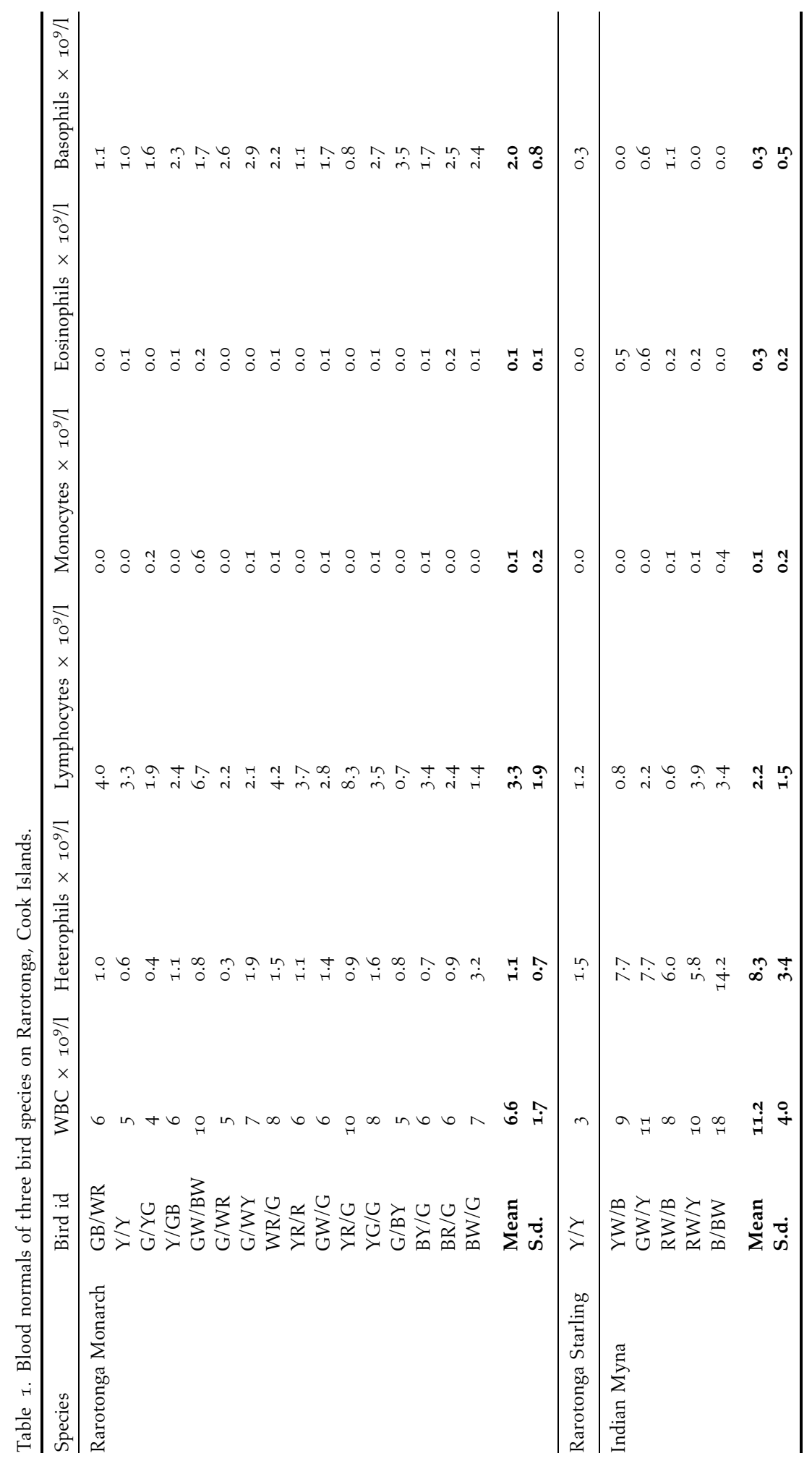




\section{Translocations}

\section{Hardware}

Plywood 'field' boxes (measuring $30 \mathrm{~cm}$ long $\times 20 \mathrm{~cm}$ wide $\times 20 \mathrm{~cm}$ tall) were built for transporting Rarotonga Monarchs across steep and slippery terrain from their capture locations to the road-end. There they were transferred to larger $(50 \mathrm{~cm}$ long $x$ $30 \mathrm{~cm} \times 30 \mathrm{~cm}$ ) plywood 'transfer' boxes that were divided into two compartments. The box design was based on those used for the successful translocation of Black Robins Petroica traversi in New Zealand (D. Merton pers. comm.). Each box had a dowelling perch, and three $25 \mathrm{~mm}$ diameter gauze-covered ventilation holes near the base of each side. These holes allowed little light in but provided some air circulation; their position below the perch meant that birds did not try to fly towards the light. A hinged and latched door in the centre of the roof section, surrounded by a muslin sleeve, enabled us to handle each bird safely in the box with little opportunity for it to escape through the opened door. The transfer boxes had a $30 \mathrm{~mm}$ thick layer of polystyrene foam glued to the sides of the box (except over the ventilation holes) to reduce noise and to maintain a more even internal temperature.

A mobile holding cage was also constructed in case birds had to be held for longer than anticipated if inter-islands flights were delayed or cancelled. This $2.5 \mathrm{~m}$ tall and $1.5 \mathrm{~m}$ diameter collapsible cylinder was made of fine nylon mesh with flaps for introducing or extracting the birds.

\section{Capture}

We decided to translocate only non-breeding birds, especially yearlingss and 2-yearolds, so that we did not unduly disrupt the breeding output of Rarotonga Monarchs in the Takitumu Conservation Area. These young birds may be more adaptable to the new conditions on Atiu, and they were also the most expendable group because many of them would normally die before securing a breeding territory on Rarotonga. The translocations were done 2 months before the breeding season, to allow the birds time to settle on Atiu, and then potentially breed in their first season there. We decided to translocate 30 birds in three batches of 10 birds at yearly intervals so that we did not take a large portion of any one cohort, and so the programme could be reviewed annually depending on the results from the previous translocations.

Capturing a sample of 10 youngsters each year was logistically practical. We considered that a founder population of 30 birds should be adequate for such a longlived species which has low variation in lifetime reproductive success (Robertson and Saul unpubl.). With the caveat that Rarotonga Monarchs passed through a population bottleneck of only 13 females in 1989 (Robertson et al. 1994), the genetic relatedness within each cohort was probably low because Rarotonga Monarchs usually raise only one or two fledglings per season; however, full siblings from different seasons may have been more frequent, because of the high persistence of pair bonds from year to year (Saul et al. 1998).

Given that familiarity of birds made no significant difference to the success of translocations of three species of forest bird in New Zealand (Armstrong et al. 1995), we decided to collect birds from a variety of sites where young birds congregated within the Takitumu Conservation Area. The birds were caught in $9 \mathrm{~m} \times 2 \mathrm{~m} \times 38$ $\mathrm{mm}$ mesh mist-nets set in dense, low (4-8 $\mathrm{m}$ tall) vegetation on ridgelines. Taped calls 
were broadcast to attract birds to the area. After capture, each bird was given a physical health check, individually colour-banded, weighed and measured. Each bird was aged (from its coloration) and sexed (from its measurements) according to criteria given by Robertson et al. (1993). All yearling and 2-year-olds were put in 'field' boxes, and carried to the road-end. They were then transferred to the larger 'transfer' boxes and supplied with water and numerous larvae of fruitfly species (Bactrocera melanotus and B. xanthodes) already present on Atiu, as in-flight meals.

\section{First translocation}

We caught the first group of 1o youngsters for translocation in August 2001. This group included seven yearlings and three 2-year-olds, and they had an even sex ratio. They were translocated to Atiu in three batches of two to five birds between 19 and 27 August. The first three birds were taken to Atiu on a charter flight, and after a formal welcoming ceremony involving landowners from both source and recipient sites, the birds were released by Atiuan landowners into a patch of forest near Lake Te Roto, Atiu $\left(20^{\circ} \mathrm{OI}^{\prime} \mathrm{S}, 158^{\circ} \mathrm{O}^{\prime} \mathrm{W}\right)$. The next seven birds were released at the same site. All the birds were released on Atiu within 18 hours of capture; seven were caught late afternoon and held overnight on Rarotonga, the other three were caught shortly after dawn and sent to Atiu on the same morning.

\section{Subsequent translocations}

Similar methods were used for the subsequent translocations. From 15 to 24 August 2002, ten yearling Rarotonga Monarchs (six females and four males) were taken to Atiu in five batches of one to five birds. They were released into a forested valley near the Atiu Villas, $1.5 \mathrm{~km}$ east of the Lake Te Roto release site. All birds were released within 19 hours of capture.

Between 15 and 19 August 2003, the final 10 youngsters (six females and four males; eight yearlings and two 2-year-olds) were translocated in four batches of one to seven birds. Most birds were released within 19 hours of capture, but one was held for 23 hours because its transfer box was inadvertently left on the aircraft and it had to be returned to Atiu on a special charter flight several hours later.

\section{Monitoring}

Atiu

George Mateariki has kept a close eye on the Rarotonga Monarchs since they were released on Atiu. His efforts have been assisted by other local people reporting sightings to him, as well as specific searches made by E. S. and visiting ornithologists.

In the 2001/2002 breeding season, a pair (a yearling female and a 2-year-old male) was found in leeward coastal forest $4.5 \mathrm{~km}$ north of the release site but they did not appear to breed. After the breeding season, E. S. and George Mateariki found another pair of yearling birds in makatea forest, but could find no evidence that they had bred.

In 2002/2003, these two pairs bred successfully in the territories established the previous year, and both raised two fledglings, the maximum family size recorded on Rarotonga. The nest of the coastal pair was built of a range of plant material and lined with needles of Casuarina, rather than built of Aerobryopsis moss as used on 
Rarotonga, and even though this was the first breeding attempt by either bird, they obviously adapted well to local conditions. After the breeding season, George Mateariki and E. S. found another pair in riverine forest near to the Atiu Villas release site, but their identity could not be determined.

In spring 2003, Eric vanderWerf, Matt Burt and Diana Dombroski searched parts of Atiu, especially the inland areas, and found 11 banded birds: four from the 2001 translocation, five from the 2002 translocation, and two of the 2003 birds. During the 2003/2004 breeding season, five pairs of these banded birds bred successfully and raised two fledglings each - two pairs were in makatea forest, two in riverine forest and one in leeward coastal forest. In May/June 2004, a minimum of 15 Rarotonga Monarchs were found by E. S., Rose Collen and Helen Gummer, including an islandbred yearling in windward coastal forest near Tarapaku Landing, $2.5 \mathrm{~km}$ from the nearest known birds (Figure 4).

The 2,700 ha island of Atiu has proven suitable for Rarotonga Monarchs, with pairs establishing territories and breeding successfully in a range of different habitat types scattered widely over the island. The 15 birds found in May/June 2004 are regarded as the absolute minimum number alive because only a small percentage of the potential habitat has been searched, much of the 884 ha of makatea forest being extremely difficult terrain to traverse.

\section{Rarotonga}

The source population on Rarotonga showed no signs of having been compromised by the removal of 30 youngsters between 2001 and 2003. The population census in August each year showed that the population of Rarotonga Monarchs on Rarotonga increased from 245 in 2001 to 283 in 2003 (after the translocated birds had been removed), and then dropped slightly to a minimum of 281 birds in 2004 (Robertson and Saul in press).

\section{Discussion}

The recovery of the Rarotonga Monarch population between 1989 and 2001 was spectacular, but all the hard work in controlling rats each breeding season could easily have been wasted if a catastrophe had struck Rarotonga. The decision to consider establishing a second, 'insurance' population was made once we felt confident that the source population would not be harmed unduly by the removal of 30 individuals to be the founders of a new population.

Although translocations of threatened birds are commonplace in conservation management in island nations such as New Zealand and the Seychelles, and have been undertaken in many other countries, little published data were available about the practical steps involved in planning, decision-making, and then translocating birds from one locality to another. This was especially true for insectivorous passerines, which are notoriously difficult to maintain for prolonged periods, even in captivity (D. Merton pers. comm.). Although parrots and pigeons have been translocated in French Polynesia (Kuehler et al. 1997, Thorsen et al. 2002), this was the first planned translocation of an insectivorous passerine within the South Pacific region.

For us, community consultation was a critically important phase in the translocation planning, because the landowners of the Takitumu Conservation Area use the presence of Rarotonga Monarchs on their land as the main drawcard for their ecotourism 


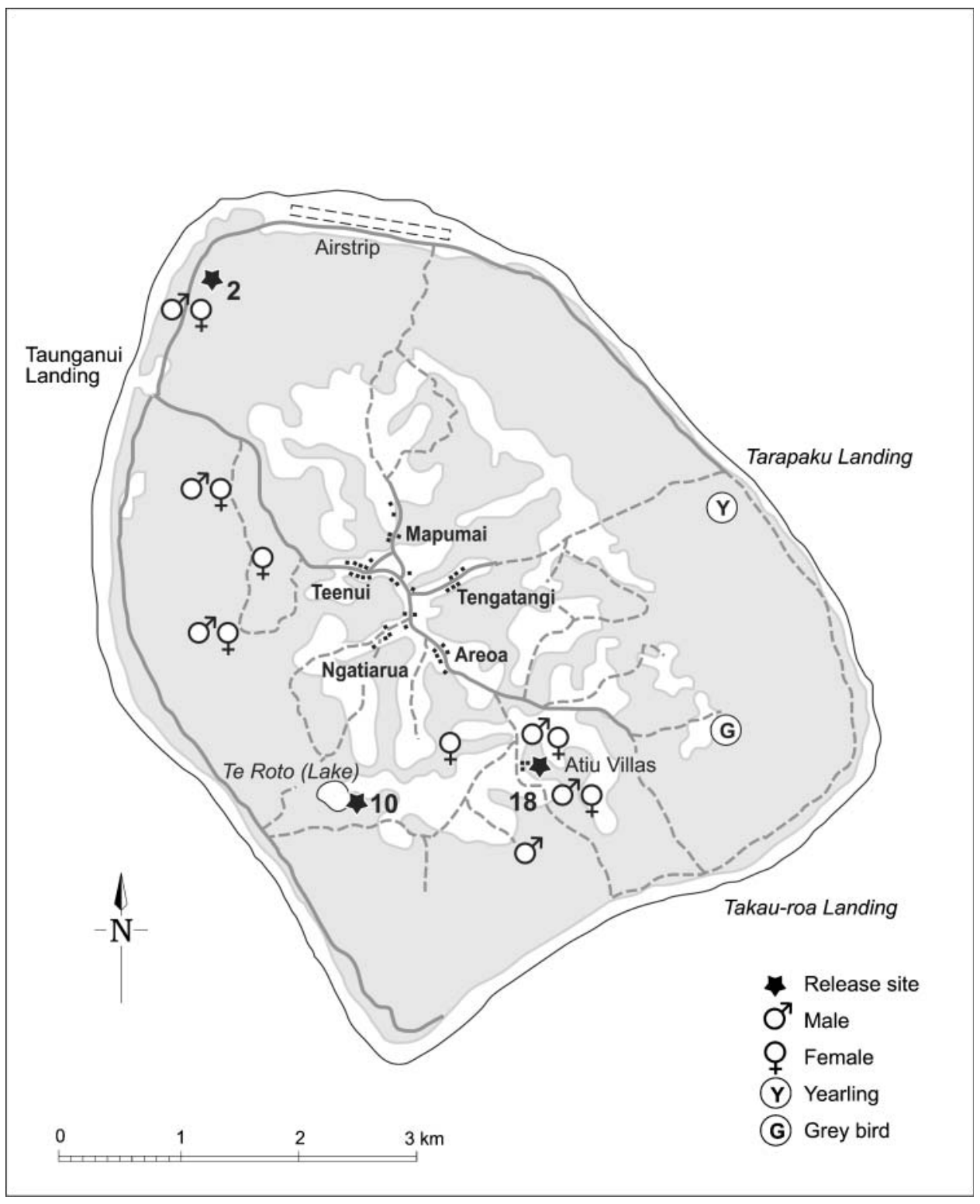

Figure 4. Map of Atiu showing location of Rarotonga Monarchs seen in May/June 2004.

business. In this case, because virtually all overseas visitors to the Cook Islands pass through Rarotonga, little revenue will be lost by ecotourists seeing them on Atiu; however, a translocation in the opposite direction might well have proven impossible from a socio-economic perspective. The Island Council on Atiu was especially keen to have Rarotonga Monarchs on their island, even if there were no historical records of their presence on Atiu. Since their arrival on the island, the Rarotonga Monarch has been a target for a small ecotourism business, and as an education resource for the island's school. 
The island assessments were based on the studies in French Polynesia that showed that good populations of Pomarea flycatchers persist only on islands free of ship rats, and our own data that showed a significant increase in breeding success and survival of Rarotonga Monarchs when rats were maintained at low levels (Robertson et al. 1998). The land-cover mapping and vegetation surveys by Franklin and Steadman (1991) and Franklin and Merlin (1992) provided a good basis for assessing the habitat availability on Atiu, even though Franklin and Steadman (1991) did not consider Rarotonga Monarchs in their assessment of potential species to translocate to the island. The suitability of habitat is always hard to assess when environments at source and destination are so different, but we were encouraged by the fact that Rarotonga Monarchs used a variety of breeding habitats on Rarotonga. It seems that they have adapted well on Atiu, especially in overcoming the absence of the main plant that forms their nests on Rarotonga. The paucity of birdlife on Atiu compared with that in pre-human times (Steadman 1991), and the absence of insectivorous birds that specialized in gleaning, suggested that competition was not likely to be an important factor. However, it was ironic that during our prolonged planning and consultation leading to the translocation of Rarotonga Monarchs to Atiu, a local community group imported Cook Islands Warblers with no consultation or planning; if these had become well established on Atiu, they would have had the potential to compete directly with Rarotonga Monarchs.

The translocation of Rarotonga Monarchs to Atiu has raised the consciousness of the Atiuan community about the many ecological, economic and human health advantages of maintaining an island free of ship rats. As a result, biosecurity efforts (rodenticide bait stations around the port) have been established to try to prevent ship rats establishing on Atiu.

It is still too early to assess the ultimate success of the translocations of Rarotonga Monarchs to Atiu, but the early indications are positive, with high nesting success and large family sizes in a variety of habitats being especially encouraging. The initial success of this translocation to a 'low' island raises the possibility that the four other threatened species of Pomarea flycatchers in French Polynesia, and other threatened passerines in the South Pacific, could be shifted to secure sites on some of the many atolls or other 'low' islands in the region that are still free of ship rats.

\section{Acknowledgements}

The Takitumu Conservation Area Committee strongly supported our efforts to establish a second population of Rarotonga Monarchs; Tom Daniels and I. K. represented the committee in discussions with Island Councils of the possible recipient islands. The members of the Island Council of Atiu, and especially Roger Malcolm, were very supportive of the concept of using Atiu as the site for this 'insurance' population, and at the same time of adding to the colour and diversity of the local birdlife. Gerald McCormack provided useful information on the distribution of rat species within the southern Cooks. Maja Poeschko, of the Totokoitu Research Station, provided fruitfly larvae for the birds, and advised on their presence on Atiu. Vitoti Tupa, Director of the Cook Islands Environment Service, supported the translocation, and accompanied the first batch of birds as the government representative. Richard Jakob-Hoff (Auckland Zoo veterinarian), and Ray Lanham (Alpha Scientific) advised us on disease screening and interpretation of the smear results. Bob Montgomerie, Jim 
Briskie and Greg Sherley helped us in the field during blood sampling. Don Merton advised us on transfer box designs, and Madeline Midwinter and Diana Dombroski helped to make the boxes and the emergency holding cage. Anna Tiraa assisted in many ways during the consultation and planning phase, and also helped with capture of the first batch of birds. Diana Dombroski helped with the capture of the first and third batches of birds and also found several banded birds on Atiu in 2003. Barb Maile, Suzanne Card and Jennifer Carpenter assisted us in catching birds for the second translocation. George Mateariki and Roger Malcolm have run the Atiu end of the operation, and have been responsible for the replenishment of rodenticide in bait stations around the port as part of the biosecurity efforts there. The Avifauna Programme of the South Pacific Regional Environment Programme, the Pacific Initiative for the Environment of the New Zealand Agency for International Development, the Takitumu Conservation Area Project and the New Zealand Department of Conservation supported the costs of the planning, assessments, translocations and monitoring. Air Rarotonga provided free transport of the birds and provided substantial discounts on charters and some monitoring trips thanks to the generosity of the managing director, Ewan Smith. Chris Edkins drew the figures, and Greg Sherley and Rod Hay improved the manuscript.

\section{References}

Armstrong, D. P., Lovegrove, T. G., Allen, D. G. and Craig, J. L. (1995) Composition of founder groups for bird translocations: does familiarity matter? Pp. 105-111 in M. Serena, ed. Reintroduction biology of Australian and New Zealand fauna. Chipping Norton, NSW, Australia: Surrey Beatty \& Sons.

Armstrong, D. P. and McLean, I. G. (1995) New Zealand translocations: theory and practice. Pacific Conserv. Biol. 2: 39-54.

BirdLife International (2000) Threatened birds of the world. Barcelona and Cambridge, U.K: Lynx Edicions and BirdLife International.

Black, J. M. (1991) Reintroduction and restocking: guidelines for bird recovery programmes. Bird Conserv. Int. 1: 329-334.

Blanvillain, C., Salducci, J. M., Tutururai, G. and Maeura, M. (2003) Impact of introduced birds on the recovery of the Tahiti Flycatcher (Pomarea nigra), a critically endangered forest bird of Tahiti. Biol. Conserv. 109: 197-205.

Butler, D. and Merton, D. (1992) The Black Robin: saving the world's most endangered bird. Auckland: Oxford University Press.

Cibois, A., Thibault, J. -C. and Pasquet, E. (2004) Biogeography of eastern Polynesian Monarchs (Pomarea): an endemic genus close to extinction. Condor 106: 837-851.

Collar, N. J., Crosby, M. J. and Stattersfield, A. J. (1994) Birds to watch 2: the world list of threatened birds. Cambridge, U.K.: BirdLife International.

Currie, D., Hill, M., Millett, J., Bristol, R., Nevill, J. and Shah, N. J. (2003) Conservation options for the critically endangered Seychelles Black Paradise-flycatcher Terpsiphone corvina. Bird Conserv. Int. 13: 97-114.

Fosberg, F. R. (1975) Vascular plants of Aitutaki. Pp. 73-84 in D. R. Stoddart and P. E. Gibbs, eds. Almost-atoll of Aitutaki: reef studies in the Cook Islands, South Pacific. Atoll Res. Bull. 180.

Franklin, J. and Merlin, M. (1992) Species-environment patterns of forest vegetation on the uplifted reef limestone of Atiu, Mangaia, Ma'uke and Miti'aro, Cook Islands. J. Vegetation Sci. 3: 3-14. 
Franklin, J. and Steadman, D. W. (1991) The potential for conservation of Polynesian birds through habitat mapping and species translocation. Conserv. Biol. 5: 506-521.

Gill, W. W. (1885) Jottings from the Pacific. London: The Religious Tract Society.

Griffith, B., Scott, J. M., Carpenter, J. W. and Reed, C. (1989) Translocation as a species conservation tool: status and strategy. Science 245: 477-480.

Griffith, B., Scott, J. M., Carpenter, J. W. and Reed, C. (1993) Animal translocations and potential disease transmission. J. Zoo Wildl. Med. 24: 231-236.

Hay, J. R. (1986) Bird conservation in the Pacific Islands. Cambridge, U.K.: International Council for Bird Preservation Study Report No. 7.

Heather, B. D. and Robertson, H. A. (200o) The field guide to the birds of New Zealand. Auckland: Viking.

Holyoak, D. T. (1980) Guide to Cook Islands birds. Nottingham: [published privately].

Holyoak, D. T. and Thibault, J. -C. (1984) Contribution à l'étude des oiseaux de Polynésie Orientale. Paris: Mémoires du Muséum National D’Histoire Naturelle Série A, Zoologie, Volume 127.

IUCN (1998) IUCN guidelines for re-introductions. Gland, Switzerland and Cambridge, U.K.: IUCN/SSC Re-introduction Specialist Group, IUCN.

Komdeur, J., Bullock, I. D. and Rands, M. R. W. (1991) Conserving the Seychelles Warbler Acrocephalus sechellensis by translocation: a transfer from Cousin Island to Aride Island. Bird Conserv. Int. 1: 177-185.

Kuehler, C., Lieberman, A., Varney, A., Unitt, P., Sulpice, R., Azua, J. and Tehevini, B. (1997) Translocation of Ultramarine Lories Vini ultramarina in the Marquesas Islands: Ua Huka to Fatu Hiva. Bird Conserv. Int. 7: 69-79.

Merlin, M. D. (1991) Woody vegetation on the raised coral limestone of Mangaia, southern Cook Islands. Pacific Sci. 45: 131-151.

Petrak, M. L. (1982) Diseases of cage and aviary birds. Philadelphia: Lea and Febiger.

Robertson, H. A., Hay, J. R. and Saul, E. K. (1993) Age and sex determination of Kakerori Pomarea dimidiata. Notornis 40: 179-187.

Robertson, H. A., Hay, J. R., Saul, E. K. and McCormack, G. V. (1994) Recovery of the Kakerori: an endangered forest bird of the Cook Islands. Conserv. Biol. 8: 1078-1086.

Robertson, H. A. and Saul, E. K. (2005) Conservation of kakerori (Pomarea dimidiata) in the Cook Islands in 2003/04. DOC Research \& Development Series 207. Wellington: Department of Conservation.

Robertson, H. A. and Saul, E. K. (in press) Conservation of kakerori (Pomarea dimidiata) in the Cook Islands in 2004/05. DOC Research \& Development Series. Wellington: Department of Conservation.

Robertson, H. A., Saul, E. K. and Tiraa, A. (1998) Rat control in Rarotonga: some lessons for Mainland Islands in New Zealand. Ecol. Manag. 6: 1-12.

Sanders, K. H., Minot, E. O. and Fordham, R. A. (1996) Juvenile dispersion and use of habitat by the endangered Kakerori Pomarea dimidiata (Monarchinae) on Rarotonga, Cook Islands. Pacific Conserv. Biol. 2: 167-176.

Saul, E. K. (1995) Towards 200o: a management plan for the kakerori's next 5 years. Rarotonga: Cook Islands Environment Service.

Saul, E. K., Robertson, H. A. and Tiraa, A. (1998) Breeding biology of the Kakerori (Pomarea dimidiata) on Rarotonga, Cook Islands. Notornis 45: 255-269.

Savidge, J. A. (1987) Extinction of an island forest avifauna by an introduced snake. Ecology 68: 66o-668.

Seitre, R. and Seitre, J. (1992) Causes of land-bird extinctions in French Polynesia. Oryx 26: 215-222.

Sherley, G. (2001) Bird conservation priorities and a draft strategy for the Pacific Islands region. Samoa: South Pacific Regional Environment Programme. 
Steadman, D. W. (1985) Fossil birds from Mangaia, southern Cook Islands. Bull. Brit. Ornithol. Club 105: 58q-66.

Steadman, D. W. (1991) Extinct and extirpated birds from Aitutaki and Atiu, southern Cook Islands. Pacific Sci. 45: 325-347.

Steadman, D. W., Greiner, E. C. and Wood, C. S. (1990) Absence of blood parasites in indigenous and introduced birds from the Cook Islands, South Pacific. Conserv. Biol. 4: 398-404.

Steadman, D. W. and Kirch, P. V. (1990) Prehistoric extinction of birds on Mangaia, Cook Islands, Polynesia. Proc. Natl. Acad. Sci. U.S.A. 87: 9605-9609.

Stoddart, D. R. (1975) Mainland vegetation of Aitutaki. 117-122 in D. R. Stoddart and P. E. Gibbs, eds. Almost-atoll of Aitutaki: reef studies in the Cook Islands, South Pacific. Atoll Res. Bull. 180.

Thibault, J. -C., Martin, J. -L., Penloup, A. and Meyer, J. -Y. (2002) Understanding the decline and extinction of monarchs (Aves) in Polynesian islands. Biol. Conserv. 108: 161-174.

Thibault, J. -C. and Meyer, J. -Y. (2001) Contemporary extinctions and population declines of the monarchs (Pomarea spp.) in French Polynesia. Oryx 35: 73-80.

Thompson, C. S. (1986) The climate and weather of the southern Cook Islands. Wellington, New Zealand: New Zealand Meteorological Service Misc. Publ. No. 188(2).

Thorsen, M., Blanvillain, C. and Sulpice, R. (2002) Reasons for decline, conservation needs, and translocation of the critically endangered upe (Marquesas Imperial Pigeon Ducula galeata), French Polynesia. DOC Science Internal Series 88. Wellington: Department of Conservation.

Towns, D. R., Daugherty, C. H. and Cromarty, P. L. (1990) Protocols for translocation of organisms to islands. Pp. 240-254 in D. R. Towns, C. H. Daugherty and I. A. E. Atkinson, eds. Ecological restoration of New Zealand islands. Wellington: Department of Conservation.

Turner, D. L. and Jarrard, R. D. (1982) K-Ar dating of the Cook-Austral chain: a test for the hotspot hypothesis. J. Volcanol. Geotherm. Res. 12: 187-220.

Van Riper, C., van Riper, S. G., Goff, M. L. and Laird, M. (1986) The epizootiology and ecological significance of malaria in Hawaiian land birds. Ecol. Monogr. 56: 327-344.

Viggers, K. L., Lindenmayer, D. B. and Spratt, D. M. (1993) The importance of disease in reintroduction programmes. Wildlife Res. 20: 687-698.

HUGH A. ROBERTSON

Department of Conservation, P. O. Box 10-420, Wellington, New Zealand. E-mail:hrobertson@ doc.govt.nz

IAN KARIKA, EDWARD K. SAUL

Takitumu Conservation Area Project, P. O. Box 3036, Rarotonga, Cook Islands.

Received 29 April 2005; revision accepted 16 September 2005 